\title{
HTLV-1 persistence in vivo: clonality, dynamics and immune response
}

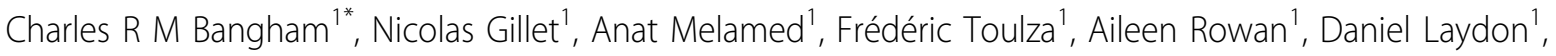 \\ Graham P Taylor', Becca Asquith $^{1}$
}

From 15th International Conference on Human Retroviruses: HTLV and Related Viruses

Leuven and Gembloux, Belgium. 5-8 June 2011

HTLV-1 propagates in the host by two parallel mechanisms: infectious spread, i.e. direct transfer of virions from cell to cell via the virological synapse; and mitotic spread, i.e. proliferation of HTLV-1-infected T cell clones. During chronic infection, mitotic spread predominates, generating very large clones in some individuals. Yet the reasons for the remarkable variation within and between hosts in the abundance of HTLV-1infected clones remain unknown.

We aim to identify and quantify the selection forces that determine the size of HTLV-1-infected T cell clones in vivo and hence the risk of the associated inflammatory and malignant diseases. We shall summarize evidence from host and viral genetics, cellular immunology and high-throughput proviral integration site analysis that:

1 . The 'quality' or efficiency of a person's geneticallydetermined cytotoxic $\mathrm{T}$ lymphocyte (CTL) response to the HBZ protein is a major determinant of that person's proviral load and the risk of inflammatory diseases.

2. The chief determinant of CTL quality is the host genotype in HLA Class 1 and Killer cell Immunoglobulin-like Receptor (KIR) loci.

3. The CTL response to the Tax protein is immunodominant but does not protect against HAM/TSP.

4. The site and orientation of the HTLV-1 provirus integrated in the $\mathrm{T}$ cell genome determine the size of each $\mathrm{T}$ cell clone in the host.

5. Negative selection on the virus dominates during chronic infection: we postulate that this selection is exerted by CTLs.

\section{Author details}

'Department of Immunology, Imperial College, London W2 1PG, UK. 2Department of Genitourinary Medicine and Communicable Diseases, Wright-Fleming Institute, Imperial College London, London, W2 1PG, UK.

Published: 6 June 2011

\section{doi:10.1186/1742-4690-8-S1-A97}

Cite this article as: M Bangham et al:: HTLV-1 persistence in vivo: clonality, dynamics and immune response. Retrovirology 2011 8(Suppl 1): A97.

* Correspondence: c.bangham@imperial.ac.uk

${ }^{1}$ Department of Immunology, Imperial College, London W2 1PG, UK

Full list of author information is available at the end of the article

Submit your next manuscript to BioMed Central and take full advantage of:

- Convenient online submission

- Thorough peer review

- No space constraints or color figure charges

- Immediate publication on acceptance

- Inclusion in PubMed, CAS, Scopus and Google Scholar

- Research which is freely available for redistribution

Submit your manuscript at www.biomedcentral.com/submit

\section{() Biomed Central}

